$\xi^{2}=1$ 줄

\title{
Spectral re-evaluation of sediment thickness within Afikpo Basin and environs, southeastern Nigeria, using high resolution aeromagnetic dataset
}

\author{
Stephen Onyejiuwaka Ibe ${ }^{1 *}$, Kevin Uche Iduma ${ }^{2}$ \\ ${ }^{1}$ Federal University Otuoke, Bayelsa State, Nigeria \\ ${ }^{2}$ Kelma Geodynamic Limited, Abuja, Nigeria \\ *Corresponding author E-mail: stphnibe@yahoo.com
}

\begin{abstract}
The discovery of hydrocarbon in the areas bordering Afikpo Basin prompted the re-evaluation of the sedimentary thickness within the basin with high resolution geophysical data. Depth to magnetic sources, sediment thickness, basement topography and structures within it were investigated using spectral analysis, analytic signal and tilt derivative of aeromagnetic data. The results show that the depth to the basement varies between 1.52 and $3.15 \mathrm{~km}$; depth to intermediate magnetic anomaly sources ranges from 0.40 to $1.05 \mathrm{~km}$ and depth to the shallow sources varies from 0.10 to $0.34 \mathrm{~km}$. Structures within the basin predominantly have NE-SW trend and the boundary between Afikpo Basin and Southwestern Basement Massif is characterised by NE-SW trending dykes with the longest dyke extending from Amasiri to Abba Omege. The results show that the basin is greatly undulated and the deformation that led to its undulation resulted in the formation of structures which could serve as traps for hydrocarbon accumulation. Sediment thickness greater than $2.3 \mathrm{~km}$ associated with some locations within the basin prompted the classification of the places as viable for hydrocarbon formation, if other conditions necessary for its generation are favourable. These places were recommended for further studies for hydrocarbon prospecting on the bases of their sediment structural complexities and thicknesses.
\end{abstract}

Keywords: Afikpo Basin; Sediment Thickness; Basement Topography; Structural Complexity; Hydrocarbon potential.

\section{Introduction}

The Afikpo basin is located in the Southern Benue Trough. The Benue Trough is a continental-large scale intraplate tectonic mega structure, which is part of the Mid-African Rift system initiated in the Latest Jurassic to Early Cretaceous and it is related to the opening of Central and South Atlantic Ocean (Benkhelil, 1989). Afikpo basin was installed alongside the Anambra Basin as flexural basins, relative to the Abakaliki Anticlinorium after the Santonian Orogeny. The sub-basin, often referred to as the Afikpo syncline rests unconformably on the folded Pre-Santonian Abakaliki Anticlinorium, filled with Pre-Santonian sediments of the Asu-River Group and the Eze-aku Group (Murat, 1972). The syncline is a narrow asymmetrical depression, gently plunging southwards; it is aerially flanked in the northeast and northwest by the Abakaliki Fold Belt, in the east by the Calabar Flank and in the south by the Niger Delta. Reyment (1965) and Murat (1972) described the Afikpo Syncline and Anambra Basin and noted that sedimentation was controlled dominantly by transgression and regressions that led to deposition in a wide variety of environments ranging from fluvial through fluvio-marine environments. Anambra and Afikpo Basins are not contiguous, having been separated by the Hawal-Kaltungo-Gboko-Abakaliki Anticlinorial Ridge. Each of the basins has its delimiting basinal boundaries (Benkhelil, 1989, Uche and Ibe, 2018) and could not be the same as suggested by Nwajide (2006).

At present, the basin has attracted the attention of geoscientists in Nigeria, owing to the discovery of crude oil and gas in its neighbouring basins (Niger Delta and Anambra) that have similar characteristics with it. This has led to various geophysical studies to delineate features favourable for hydrocarbon formation and accumulation in the basin. Previous geophysical studies on the study area (Onwuemesi 1995; 1997; Ugbor and Okeke 2010; Onuba et al. 2013; Opara et al. 2014; Obi and Obeten 2017) dwelt more on the sediment thickness and petroleum potentials, using forward and inverse modelling technique, spectral analysis or half width method. These studies made use of obsolete method, low resolution airborne magnetic data, one-dimensional profiles for depth modelling or high spectral grid cell size to generate results. Forward and inverse modelling of one-dimensional profiles for depth modelling is less accurate, as the threedimensional effects of geologic bodies are not considered and high spectral grid cell size yields low resolution results. However, Ehinola et al. (2005) carried out the analysis of one of the basin's strata, the Nkporo Shale (dark grey and highly fissile shale with interbeds of sandy shale, siltstone and mudstone), to assess its petroleum potential by sedimentological analysis and Rock-Eval pyrolysis and the results show that the Total Organic Carbon (TOC) range exceeds the minimum value usually required for potential petroleum source rocks. The results also indicated that the shale is presently thermally immature. Hydrocarbon trapping capacity in Nkporo Shale is possible by the presence of several N-S trending normal faults, and other microstructures related to the Post-Santonian tensional regime in the Benue Trough (Odunze and Obi, 2013). Also, another stratum, Imo Shale, which marks the onset of a transgression in the basin during 
the Paleocene, contains significant amount of organic matter and may be a potential source for hydrocarbons in the basin (Ehinola et al. 2005).

One of the fundamental features that affect the formation of hydrocarbon in a basin is the thickness of the sediment (Wright et al. 1985, Anyanwu and Mamah, 2013). Hence, there was need to re-evaluate the thickness of Afikpo Basin with high resolution geophysical data. This study used high resolution aeromagnetic dataset and a smaller spectral grid cell size to appraise the hydrocarbon potential of the study area. This was accomplished by the determination of the depth to magnetic sources, sediment thickness, basement topography and structures within the basin.

\subsection{The study area}

The study area is bounded by longitudes $7^{\circ} 30^{\prime} 00^{\prime \prime} \mathrm{E}$ to $8^{\circ} 30^{\prime} 00^{\prime \prime} \mathrm{E}$ and latitudes $5^{\circ} 30^{\prime} 00^{\prime \prime} \mathrm{N}$ to $6^{\circ} 00^{\prime} 00^{\prime \prime} \mathrm{N}$. The area borders Abakaliki to the north, Biakpan to the south, Ikom and Mkot to the east and Okigwe and Owerrinta to the west. The area can be accessed through Abakaliki - Afikpo Expressway, Umuahia - Afikpo Expressway and Ikot Ekpene - Afikpo Expressway. It falls within the humid tropical region with two distinct seasons, the rainy season, from March to October, and dry season, from November to March.

The Southern Benue Trough comprises the tectonically inverted Abakaliki Anticlinorium, Afikpo and Anambra Basins flanking the anticlinorium to the east and west respectively. That is, the basin was formed from the evolution of the Southern Benue Trough (Murat, 1972). The stratigraphic setting of the area (Fig. 1) comprises two major sedimentary basins, the Abakaliki Basin and the Afikpo Subbasin, with sediments deposited by three sedimentary cycles. The first two cycles belong to the Pre-Santonian sediments (Albian-Asu River Group, Cenomanian to Turonian Eze-Aku Group and Coniacian Agwu Formation), while the third cycle belongs to the PostSantonian sediments which are found in the Afikpo Basin (Reyment, 1965, Murat, 1972, Nwajide, 2013). Table 1 summerises the Stratigraphic Sequence of Southern Benue Trough and Afikpo Basin. The sub-basin is generally filled by a thick sedimentary sequence of Campanian-Maastrichian deposits of shale, sandstone, siltstone, mudstone and coal (Simpson, 1954, Reyment, 1965, Nwajide, 2013). The depositional environment comprised transitional/shoreline, mudflats and swamps and were deposited during a largely regressive phase of sea level changes.

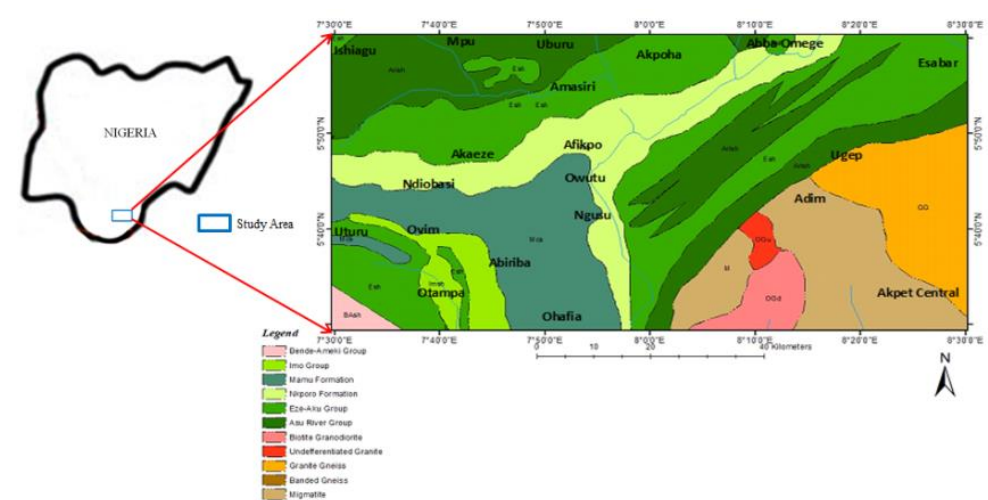

Fig. 1: Geology Map of the Study Area.

Table 1: Stratigraphic Sequence of Southern Benue Trough and Afikpo Basin (Adopted and modified from Reyment, 1965, Murat, 1972 and Hoque, 1977)

\begin{tabular}{|c|c|c|c|}
\hline Period & Age & Formation & $\begin{array}{l}\text { Approximate Thickness } \\
(\mathrm{m})\end{array}$ \\
\hline & Eocene & Bende-Ameki & 1900.00 \\
\hline Tertiary & Paleocene & Imo Group & 1000.00 \\
\hline \multirow{5}{*}{ Upper Cretaceous } & & Mamu & 1000.00 \\
\hline & Campanian & Nkporo & 475.00 \\
\hline & Santonian & Diastem (Uncomfomity) & \\
\hline & Coniacian & Awgu Shale (Unconformity in Afikpo) & \\
\hline & $\begin{array}{l}\text { Turonian } \\
\text { Cenomanian }\end{array}$ & Ezeaku Group & 100.00 \\
\hline Lower Cretaceous & Albian & Asu River Group & 1830.00 \\
\hline
\end{tabular}

\section{Materials and method}

The aeromagnetic dataset used for this study is from the high-resolution airborne magnetic survey coverage in Nigeria in 2009 , carried out by Fugro Airborne Service. Two aeromagnetic maps of total magnetic field intensity of sheet numbers 312 and 314 were used. The magnetic data, which cover an area of about $6,050 \mathrm{~km}^{2}$, were acquired along a series of $\mathrm{NW}-\mathrm{SE}$ flight lines at $500 \mathrm{~m}$ line spacing, 20 $\mathrm{km}$ tie lines spacing and at $100 \mathrm{~m}$ terrain clearance. The maps were published by Nigerian Geological Survey Agency (NGSA), on a scale of $1: 100,000$.

In this study, the total magnetic intensity grid (Fig. 2) was generated using a minimum curvature algorithm at a grid cell size of $100 \mathrm{~m}$. The digitized data were filtered using a low pass Fourier domain sub-routine filter to eliminate unwanted wavelengths and to pass longer wavelengths. Reduction-to-pole (RTP) transformation was applied to the aeromagnetic data to minimize polarity effects. A computer program, Geosoft (Oasis Montaj, version 8.4), was used to derive the residual magnetic values by subtracting values of the regional fields from the total magnetic field intensity values at the grid cross point. 


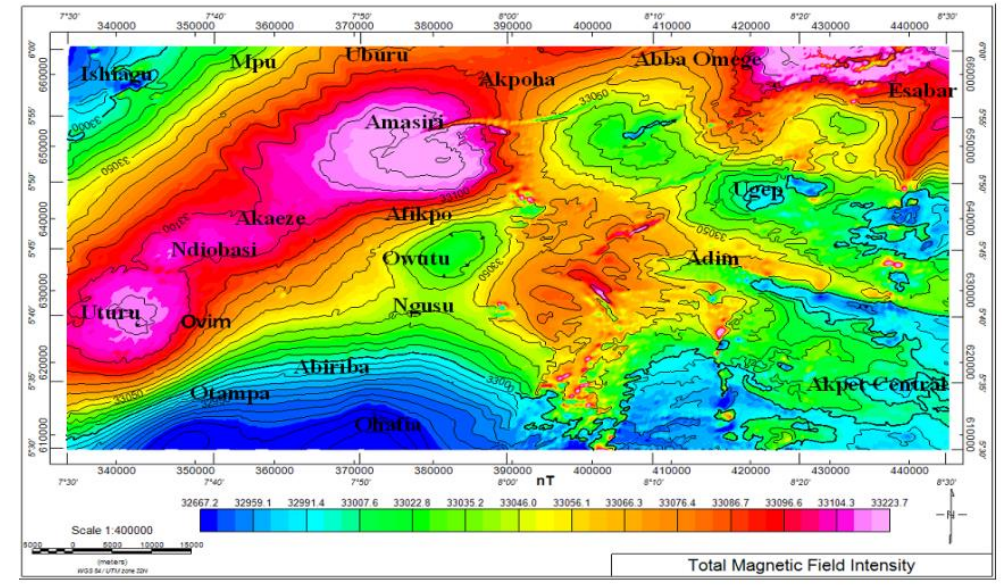

Fig. 2: Total Magnetic Intensity Map of the Study Area.

\subsection{Spectral analysis of the aeromagnetic data}

Spectral analysis is a technique for quantitative studies of large and complex aeromagnetic dataset. This method was developed by Spector and Grant (1970). In this study, using a method similar to Bhattacharyya and Leu (1977) and Okubo et al. (1985), initial computation of the depths to centroid of magnetic bodies $\left(\mathrm{Z}_{1}\right)$ was followed by the estimation of the depths to intermediate $\left(\mathrm{Z}_{2}\right)$ and uppermost boundaries $\left(\mathrm{Z}_{3}\right)$ respectively, of the magnetized sources. A plot of the logarithm of the power spectrum versus frequency usually shows straight-line segments which decrease in slope with increasing frequency, and the slopes of the segments give estimates of the depths to the magnetic sources. These depth values were determined by fitting a straight line through the high, intermediate and low wave number parts of their respective radial averaged power spectrum. The depths of the anomaly sources causing the magnetic anomalies were calculated using the relation (Eq. 1) from the radial wave number curves.

$\mathrm{Z}_{\mathrm{i}}=\frac{\ln \Phi_{\Delta \mathrm{T}}\left(\mathrm{k}_{\mathrm{i}+1}\right)-\ln \Phi_{\Delta \mathrm{T}}\left(\mathrm{k}_{\mathrm{i}}\right)}{2\left(\mathrm{k}_{\mathrm{i}+1}-\mathrm{k}_{\mathrm{i}}\right)}$ for $\mathrm{i}=1,2, \ldots$

Where $\Phi_{\Delta \mathrm{T}}$ is the power spectrum of the reduced to pole magnetic data, $\mathrm{k}$, angular frequency and $\mathrm{Z}$ is the depth to the anomaly sources (Maden, 2010).

\subsection{Analytic signal of the aeromagnetic data}

Nabighian (1972) developed the concept of analytical signal. Roest et al. (1992) define the analytical signal as a function that relates the magnetic field by the derivatives. The analytical signal (AS) transformation is independent of the direction of the magnetization of its source; therefore, it places the magnetic signature directly over its causative body (Silva et al. 2003; Asadi and Hale, 1999). Analytic signal (AS) is given as the square root of the sum of the squares of the derivatives in the $\mathrm{x}, \mathrm{y}$ and $\mathrm{z}$ directions.

$\mathrm{AS}=\sqrt{\left(\frac{\partial \mathrm{T}}{\partial \mathrm{x}}\right)^{2}+\left(\frac{\partial \mathrm{T}}{\partial \mathrm{y}}\right)^{2}+\left(\frac{\partial \mathrm{T}}{\partial \mathrm{z}}\right)^{2}}$

Where $\mathrm{T}=$ Magnitude of the total magnetic field

\subsection{Tilt angle derivative of the aeromagnetic data}

Tilt derivatives (TDR) are extremely useful in mapping out shallow basement structures. Verduzco et al. (2004) showed that TDR performs an automatic-gain-control (AGC) filter which equalizes the response from both weak and strong anomalies, hence, providing an effective way to trace out striking anomalies. Tilt angle derivative locates the edges of formations, especially at shallow depths, by using the theory that the zero contours are the edges of the formation (Salem et al. 2007). The tilt derivative introduced by Miller and Singh (1994) and later by Verduzco et al. (2004) is defined as:

$\mathrm{TDR}=\arctan \left(\frac{\mathrm{VDR}}{\mathrm{THDR}}\right)=\arctan \left(\frac{\frac{\partial \mathrm{T}}{\partial \mathrm{z}}}{\sqrt{\left[\frac{\partial \mathrm{T}}{\partial \mathrm{x}}\right]^{2}+\left[\frac{\partial \mathrm{T}}{\partial \mathrm{y}}\right]^{2}}}\right)$

Where $\mathrm{T}$ is the observed magnetic anomaly at $(\mathrm{x}, \mathrm{y})$.

\section{Results and discussion}

The residual magnetic field map of the study area (Fig. 3) shows that the intensity ranges from $-277.5 \mathrm{nT}$ to $219.0 \mathrm{nT}$. The basin is characterized by long wavelength signature within Amasiri, Akpoha, Afikpo, Owutu, Ngusu, Abiriba, Otampa, Uturu and Akaeze Areas and this is indicative of high depth to magnetic basement at those places. Places like Ugep, Esabar, Abba Omege, Adim and Akpet Central are characterized by short wavelength (high frequency bodies), which is interpreted geologically to have resulted from the basement complex rock of Southeastern Basement Massif. 


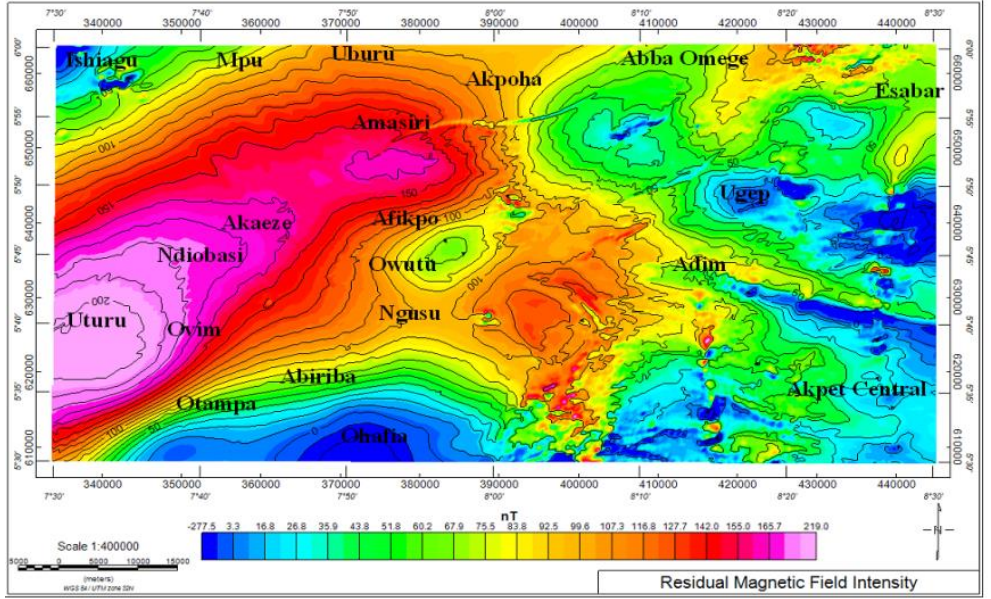

Fig. 3: Residual Magnetic Field Intensity Map of the Study Area.

In order to increase the resolution of the resultant depth values, the TMI block of the study area was subdivided into 18 spectral cells (Fig. 4) of $18.3 \mathrm{~km}$ by $18.3 \mathrm{~km}$ to accommodate longer wavelengths so that maximum depths could be investigated. The graphs of the logarithm of the spectral energies against frequencies for the 18 spectral cells were plotted and the graph for one of the blocks, C6, is presented in Fig. 5. For each cell, three linear segments were defined, indicating three magnetic source depth layers (shallow, intermediate and deep) in the study area. Each linear segment group points are due to anomalies caused by bodies occurring within a particular depth range (Nwosu et al. 2013). The line segments in the higher frequency ranges are from the shallow sources and the lower harmonics are indicative of sources from deep - seated bodies. For each of the line segments the gradient $m$ is given as:

$\mathrm{m}=\frac{\log (\mathrm{F})}{\mathrm{Kr}}$

The calculated gradient of each line segment is regarded as the depth to the magnetic source. The three depth estimates $\left(Z_{1}, Z_{2}\right.$ and $\left.Z_{3}\right)$ for each of the eighteen (18) spectral blocks are given on Table 2.

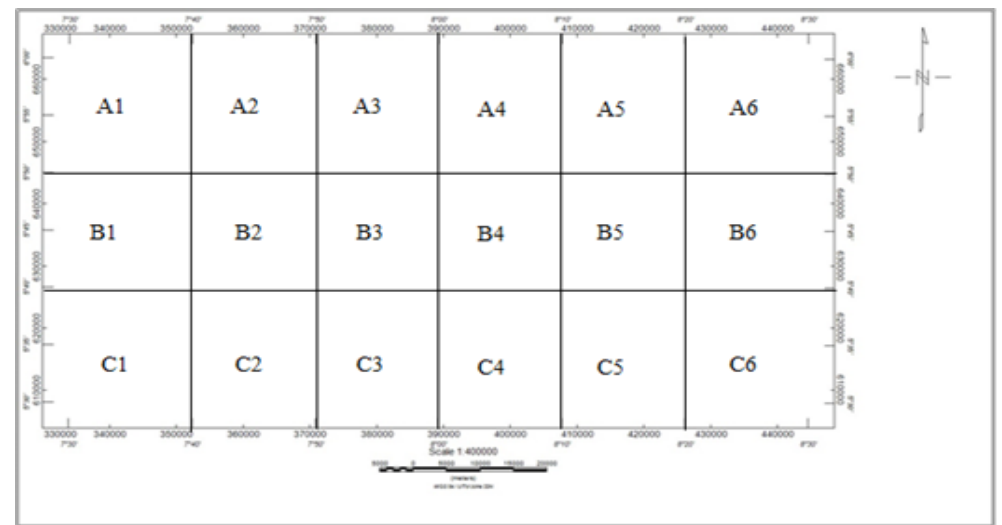

Fig. 4: Spectral Cell Blocks for Spectral Analysis.

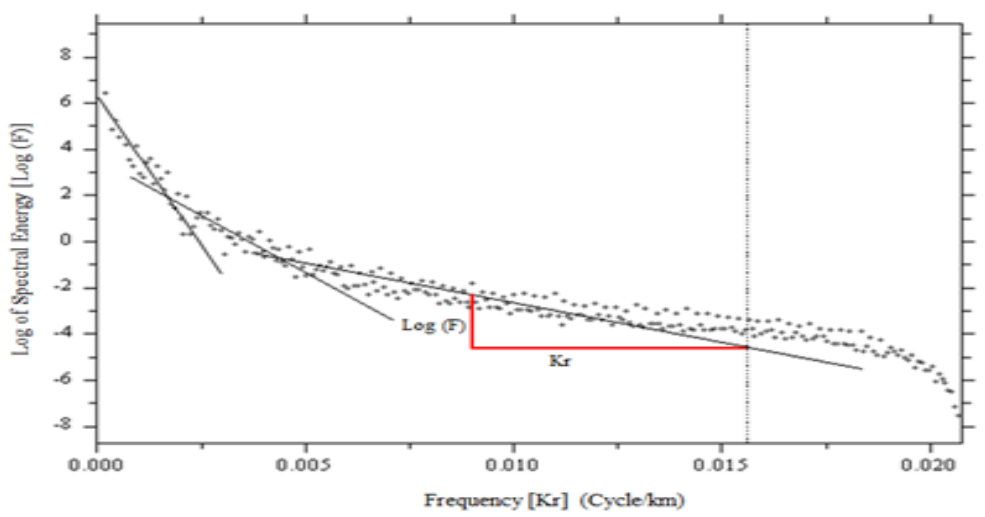

Fig. 5: Spectrum Energy Plot of C6.

Table 2: Calculated Depth to Magnetic Sources from Spectral Analysis

\begin{tabular}{llll}
\hline Spectral Block Name & Depth to Basement $\left(\mathrm{Z}_{1}\right)(\mathrm{m})$ & $\begin{array}{l}\text { Depth to Intermediate } \\
\text { Boundary } \\
\left(\mathrm{Z}_{2}\right)(\mathrm{m})\end{array}$ & $\begin{array}{l}\text { Depth to Top } \\
\text { Boundary } \\
\left(\mathrm{Z}_{3}\right)(\mathrm{m})\end{array}$ \\
\hline A1 & 2736.283 & 1050.754 & 245.391 \\
A2 & 1644.690 & 579.890 & 241.133 \\
\hline
\end{tabular}




\begin{tabular}{lrrr}
\hline A3 & 2271.544 & 679.575 \\
A4 & 2688.426 & 803.481 & 306.736 \\
A5 & 2133.256 & 623.444 & 298.554 \\
A6 & 2552.560 & 985.245 & \\
B1 & 3150.970 & 836.747 & \\
B2 & 2695.426 & 886.464 & 274.332 \\
B3 & 2523.165 & 676.881 & 322.528 \\
B4 & 1958.098 & 679.263 & 196.382 \\
B5 & 1360.543 & 433.203 & 275.410 \\
B6 & 1922.224 & 550.540 \\
C1 & 2676.292 & 586.660 \\
C2 & 1397.384 & 568.330 \\
C3 & 2012.482 & 808.345 \\
C4 & 1621.709 & 827.814 \\
C5 & 1515.784 & 395.983 \\
C6 & 3013.697 & 749.610 \\
\hline
\end{tabular}

The spectral analysis of the airborne magnetic data over the basin has revealed three main magnetic anomaly depth sources (Fig. 5 and Table 2). These are the deep, intermediate and shallow magnetic anomaly sources. The occurrence of three or more depth sources within the basin is accredited to the complexity of the basin. The deep sources are interpreted to be from the basement and plutonic/hypabyssal rocks, known to be associated with the basin. The depth to the deep magnetic source anomalies ranges from 1515.784 to $3150.97 \mathrm{~m}$, with an average of $2333.37 \mathrm{~m}$; this represents the basement depth. The depth to the intermediate anomaly sources ranges from 395.983 to $1050.754 \mathrm{~m}$, with an average of $723.36 \mathrm{~m}$. This represents the depth to the plutonic rocks within the basin. The shallow anomaly sources depth varies from 99.966 to $342.599 \mathrm{~m}$, with an average of $221.28 \mathrm{~m}$. This may be regarded as the depth to magnetic intrusions into the sediment within the basin. Both intermediate and shallow depth magnetic sources were interpreted to have been emplaced during Santonain Orogeny that led to the basin formation. Active magmatisms have been reported in the neighbouring Benue Trough, with Ofoegbu and Odigi (1989), confirming the close associations between magmatisms, intrusives, mineralizations and fractures in the area.

The basement depth of the study area was plotted to produce a 2D image of the basement surface (Fig. 6). The shallowest depths, less than $1840.369 \mathrm{~m}$, were delineated around Ugep, Adim and Akpet Central Areas, representing the basement complex rock of southwestern Nigeria. The shallow depths observed around Ishiagu and Uturu corresponds to the shallow depth of the Southern Benue Trough. Intermediate depths ranging from 840.369 to $2408.833 \mathrm{~m}$ were observed at Akpoha, Abba Omege, Amasiri, Owutu, Ngusu, Ohafia, Abiriba and Uburu Areas. The deepest basement depths, greater than $2408.833 \mathrm{~m}$, were delineated at Mpu, Afikpo, Akaeze, Ndiobasi, Ovim and Otampa Areas.

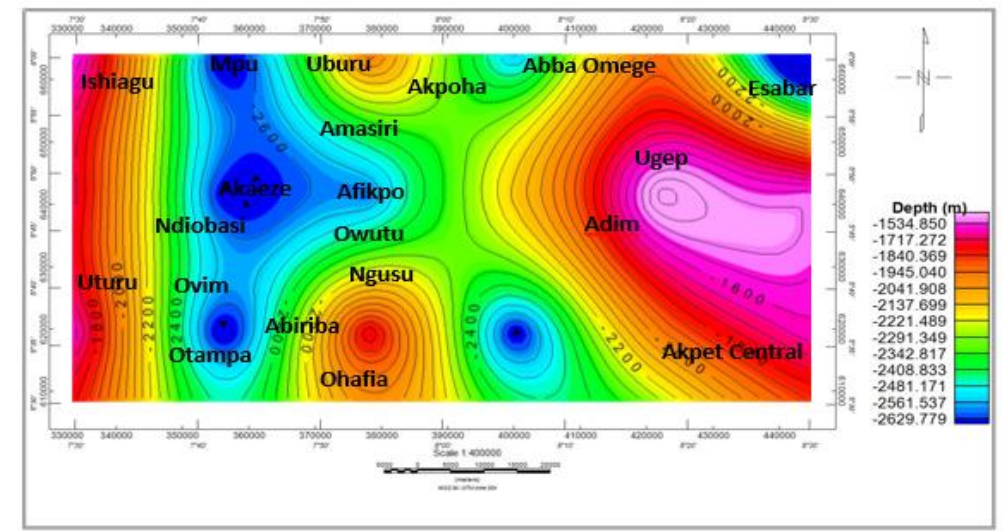

Fig. 6: Spectral Depth Map of the Basement Depth.

The depth to basement rocks is synonymous with the thickness of overburden sediment and this is very significant to the hydrocarbon generation potential of a place (Nwosu, 2014). For example, it is known that the minimum thickness of sediment required to achieve the threshold temperature of $115^{\circ} \mathrm{C}$ for the commencement of oil formation from organic remains is $2.3 \mathrm{~km}$ when all other conditions for hydrocarbon accumulation are favourable and the average temperature gradient of $1{ }^{\circ} \mathrm{C}$ for $30 \mathrm{~m}$ obtainable in oil rich Niger Delta is applicable (Wright et al. 1985). Based on this fact, colour ramp filter (Fig. 7) was applied to highlight areas with sediment thickness greater than or equal to 2.3 and the places are most likely viable for hydrocarbon formation. The places that satisfy this criterion (sediment thickness $\geq 2.3 \mathrm{~km}$ ) for hydrocarbon formation within the basin are Afikpo, Amasiri, Mpu, Akaeze, Esabar, Ndiobasi, Ovim, Otampa, and Owutu Areas. 


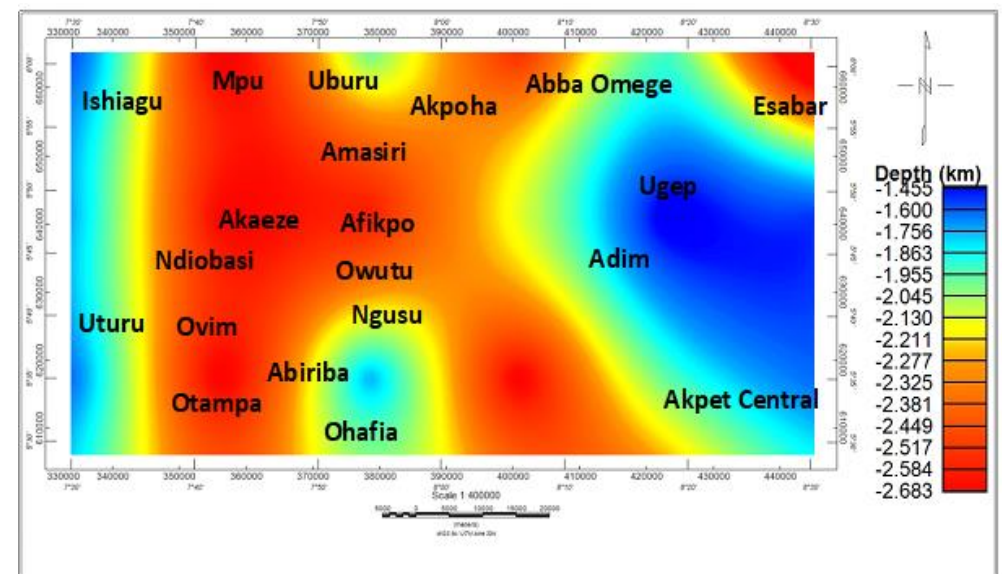

Fig. 7: Colour Ramp Spectral Basement Depth Map of the Study Area.

The undulation of the basement was delineated by producing a 3D Model of the basement surface (Fig. 8). The basin was observed to be greatly undulated owing to the deformation of the basement during the Santonian Orogeny. The Afikpo Syncline and Abakaliki Anticlinorium are very visible on the 3D basement model of the study area. The model also shows a high basement ridge separating the Afikpo Basin and the Eastern Niger Delta Basin located around Ohafia Area. The undulation around Ugep Area is most likely as a result of the intense deformation associated with the Southwestern Basement Complex of Nigeria. The deformation that led to the undulation of the basement resulted in the formation of structures which could serve as traps for hydrocarbon accumulation.

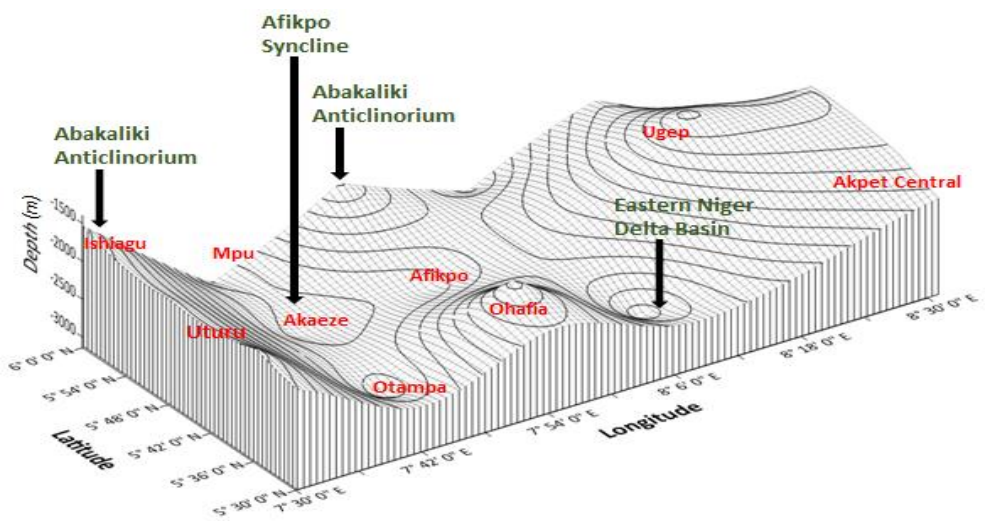

Fig. 8: 3D Depth Image of the Basement Surface of the Study Area.

\subsection{Structural analysis of the basin}

Structural analysis of the study area was carried out by applying both analytic signal (AS) and tilt derivative filter (TDR) on the magnetic field data. The analytical signal (AS) and tilt derivative filter (TDR) maps of the study area are presented in Figs. 9 and 10 respectively. Both analysis methods delineated high magnetic bodies around Ishiagu Area; these correspond to the massive intrusives which correlate with the intrusive rocks of the Southern Benue Trough. Uburu, Mpu, Amasiri, Akaeze, Owutu, Ngusu and Ndiobasi Areas are generally characterised by low amplitude, long wavelength signatures which suggest that the places are having high depth to magnetic basement. This lends support to the result of the spectral analysis which associated the places with thickest sediments compared with other places within the study area. Numerous NE-SW trending structures were delineated around Uburu, Mpu, Amasiri, Akaeze, Owutu, Ngusu and Ndiobasi Areas, indicative of structures/shear zones formed during the formation of the Benue Trough during the opening of Gondwana Super-continent (Nwajide, 2013). Magnetic bodies within Afikpo Basin majorly have NE-SW trend, as defined by high frequency and high magnitude anomalies around Afikpo, Owutu, Ngusu, Ndiobasi, Ovim, Uturuu and Abiriba Areas. These magnetic anomalies are interpreted as responses from the intrusive rocks emplaced during the Santonian Orogeny. The boundary between the Afikpo Basin and the Southwestern Basement Massif is interpreted to be characterised by NE-SW trending dykes (D1 - D6) (Fig. 9), with the longest extending from Amasiri to Abba Omege. 


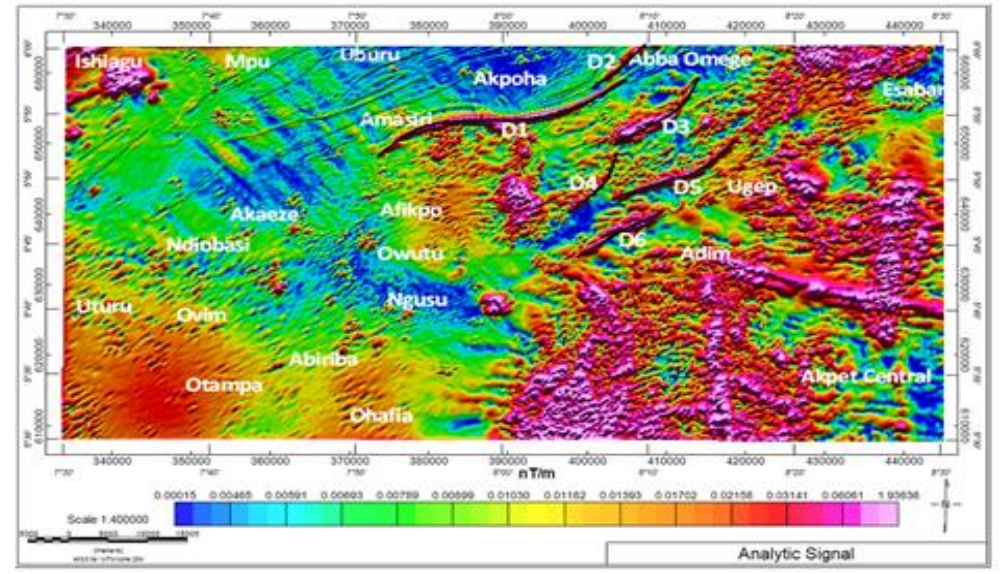

Fig. 9: Analytic Signal Map of the Study Area.

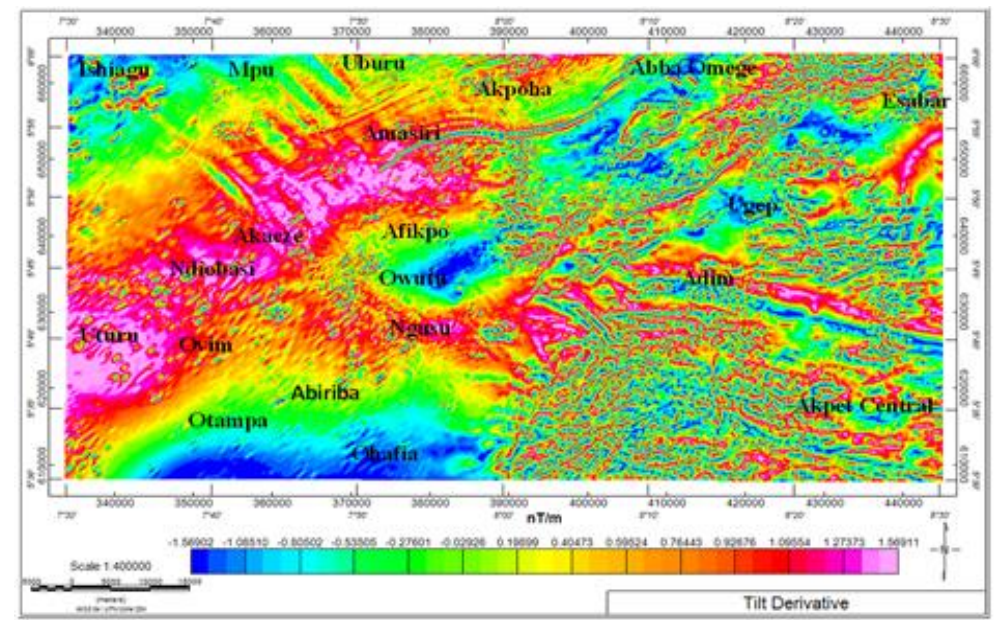

Fig. 10: Tilt Derivative Map of the Study Area.

\section{Conclusion}

The spectral analysis of the airborne magnetic data over Afikpo Basin delineated three main magnetic anomaly depth sources accredited to the complexity of the basin. The depth to the deep magnetic source anomalies or the basement and plutonic/hypabyssal rocks, known to be associated with the basin, ranges from about 1.52 to $3.15 \mathrm{~km}$, with an average of $2.33 \mathrm{~km}$. The depth to the intermediate anomaly sources or plutonic rocks within the basin ranges from about 0.40 to $1.05 \mathrm{~km}$, with an average of $0.72 \mathrm{~km}$. The depth to the shallow anomaly sources or magnetic intrusions into the sediment within the basin varies from about $0.10 \mathrm{~km}$ to $0.34 \mathrm{~km}$, with an average of 0.22 $\mathrm{km}$. The structures within the basin predominantly have NE-SW trend and the boundary between Afikpo Basin and the Southwestern Basement Massif, which is characterised with about six NE-SW trending dykes, was delineated, with the longest dyke extending from Amasiri to Abba Omege Areas. The deformation that led to the undulation of the basement resulted in the formation of structures which could serve as traps for hydrocarbon accumulation. Some places within the basin, were recommended for further studies for hydrocarbon prospecting on the bases of their sediment structural complexities and thicknesses.

\section{Acknowledgement}

The authors wish to acknowledge with gratitude the Nigerian Geological Survey Agency (NGSA) for giving us access to the data used in this research study.

\section{References}

[1] Anyanwu, G., and Mamah, L. (2013). Structural interpretation of Abakaliki-Ugep; using airborne magnetic and Landsat thematic mapper (TM) data. Journal of Natural Sciences Research, Vol. 3, pp. 137-148.

[2] Asadi, H.H. and Hale, M. (1999). Integrated analysis of aeromagnetic, Landsat TM and mineral occurrence data for epithermal gold exploration in northwest Iran. 13th International Conference on Applied Geologic Remote Sensing, Vancouver. British Columbia.

[3] Benkhelil, J. (1989). The origin and evolution of the Cretaceous Benue Trough (Nigeria). Journal of African Earth Sciences (and the Middle East). Vol. 8, pp. 251-282. https://doi.org/10.1016/S0899-5362(89)80028-4.

[4] Bhattacharyya B.K. and Leu L.K. (1977). Spectral analysis of gravity and magnetic anomalies due to rectangular prismatic bodies. Geophysics, vol. 42, no. 1, pp. 41-50. https://doi.org/10.1190/1.1440712.

[5] Ehinola, O.A. Sonibare, O.O. Falode, O.A. and Awofala, B.O. (2005). Hydrocarbon Potential and Thermal Maturity of Nkporo Shale from Lower Benue Trough, Nigeria. Journal of Applied Sciences, vol. 5, pp. 689-695. https://doi.org/10.3923/jas.2005.689.695.

[6] Hoque, M. (1977). Petrographic differentiation of tectonically controlled Cretaceous sedimentary cycles, Southeastern Nigeria. Sedimentary Geology, vol. 17, pp. 235-245. https://doi.org/10.1016/0037-0738(77)90047-1.

[7] Maden N. (2010). Curie-point depth from spectral analysis of magnetic data in Erciyes Stratovolcano (Central TURKEY). Pure and Applied Geophysics, vol. 167, pp. 349-358. https://doi.org/10.1007/s00024-009-0017-0. 
[8] Miller, G.H. and Singh, V. (1994). Potential field tilt — a new concept for location of potential field sources. Journal of Applied Geophysics, vol. 32, pp. 213-217. https://doi.org/10.1016/0926-9851(94)90022-1.

[9] Murat R.C. (1972). Stratigraphy and Paleogeography of the Cretaceous and Lower Tertiary of Southern Nigeria In: Dessauvagie, T. F. J. and Whiteman, A. J. (eds), African Geology. Ibadan: University of Ibadan, Nigeria, pp. 201-266.

[10] Nabighian M.N. (1972). The analytical signal of two-dimensional magnetic bodies with polygonal cross-section; its properties and use for automated anomaly interpretation. Geophysics, vol. 37, no. 3, pp. 507-517. https://doi.org/10.1190/1.1440276.

[11] Nwajide, C.S. (2006). Outcrop analogies as a learning facility for subsurface practitioners: the value of geology field trips. Petroleum training journal, vol.3, pp.58-68.

[12] Nwajide, C.S. (2013). Geology of Nigeria's sedimentary basins. Lagos: CSS Bookshops Ltd. Chapter 11, Niger Delta Basin, pp. 347 - 518.

[13] Nwosu, O.B. (2014). Determination of magnetic basement depth over parts of Middle Benue Trough by source parameter imaging (SPI) technique using HRAM. International Journal of Scientific and Technology Research vol. 3, no. 1, pp. 262-271.

[14] Nwosu O.B, Umego M.N. and Onuba L.N. (2013). Spectral re-evaluation of the magnetic basement depth over parts of Middle Benue Trough Nigeria using HRAM. International Journal of Scientific and Technology Research, vol. 2, pp. 111-119.

[15] Obi D.A and Obeten O.E (2017). Aeromagnetic mapping of basement relief features in parts of Lower Benue Trough (Afikpo - Ugep): Implications on hydrocarbon prospectivity south - east, Nigeria. Global Journal of Pure and Applied Sciences, vol. 23 no. 2 , pp. $287-299$. https://doi.org/10.4314/gjpas.v23i2.9.

[16] Odunze, S.O. and Obi, G.C. (2013). Sedimentology and sequence stratigraphy of the Nkporo Group (Campanian-Maastrichtian), Anambra Basin, Nigeria. Journal of Palaeogeography, vol. 2, no. 2, pp. 192-208. https://doi.org/10.3724/SP.J.1261.2013.00026.

[17] Ofoegbu C.O. and Odigi, M.I. (1989). Basement structures and ore mineralization in the Benue Trough. In: Ofoegbu, C.O. (ed), The Benue Trough: Structure and Evolution, Earth Evolution Science, pp. 239-248.

[18] Okubo Y., Graf R.J., Hansen R.O., Ogawa K. and Tsu H. (1985). Curie point depths of the Island of Kyushu and surrounding areas, Japan. Geophysics, vol. 50, pp. 481-494. https://doi.org/10.1190/1.1441926.

[19] Onwuemesi A.G. (1995). Interpretation of magnetic anomalies from the Anambra Basin of southeastern Nigeria. [dissertation]. Awka: Nnamdi Azikiwe University Awka, Nigeria.

[20] Onwuemesi, A.G. (1997). One dimensional spectral analysis of aeromagnetic anomalies and Curie depth isotherm in the Anambra Basin of Nigeria. Journal of Geodynamics, vol. 23, no. 2, pp. 95 - 107. https://doi.org/10.1016/S0264-3707(96)00028-2.

[21] Onuba, L.N., Onwuemesi, A.G., Egboka, B.C., Anudu, G.K. and Omali, A.A. (2013). A review of hydrocarbon prospects in the Lower Benue Trough, Nigeria: another insight from potential field study. American Association of Petroleum Geologists Annual Convention and Exhibition, Pittsburgh, Pennsylvania. May 19 - 22, 2013.

[22] Opara, A.I., Onyewuchi, R.A., Onyekuru, S.O., Okonkwo, A.C., Nwosu, I.E., Emberga, T.T. and Nosiri, O.P. (2014). Structural interpretation of the Afikpo Sub-basin: evidences from airborne magnetic and Landsat ETM data. Elixir International Journal: Earth Science, vol. 71, pp. 2454624552.

[23] Reyment, R. A., 1965. Aspects of the Geology of Nigeria: The stratigraphy of the Cretaceous and Cenozoic deposits. University of Ibadan Press: pp. 124-135.

[24] Roest, W. R., Verhoef, J. and Pilkington, M. (1992). Magnetic interpretation using 3-D analytic signal. Geophysics, vol. 57, no. 1, pp. 116-125. https://doi.org/10.1190/1.1443174.

[25] Salem, A., Williams, S., Fairhead, J., Ravat, D. and Smith, R. (2007). Tilt-depth method: a simple depth estimation method using first-order magnetic derivatives. The Leading Edge, vol. 26, pp. 1502-1505. https://doi.org/10.1190/1.2821934.

[26] Silva, A.M., Pires, A.C., McCafferty, A., Moraes, R. and Xia, H. (2003). Application of airborne geophysical data to mineral exploration in the uneven exposed terrains of the Rio Das Velhas Greenstone Belt. Revista Brasileira de Geociências, vol. 33, no. 2, pp. 17-28. https://doi.org/10.25249/0375-7536.200333S21728.

[27] Simpson, A. (1954). The Nigerian coalfield: The geology of parts of Onitsha, Owerri and Benue Provinces. Bulletin: Geological Survey of Nigeria, no. 24 , pp. $1-31$.

[28] Spector, A. and Grant, F.S. (1970). Statistical models for interpretation of aeromagnetic data. Geophysics, vol. 35, no. 2, pp. 197 - 359. https://doi.org/10.1190/1.1440092.

[29] Uche, I. and Ibe, S.O. (2018). Defining the geometry of Anambra and Afikpo Basins, Southeastern Nigeria, using high resolution aeromagnetic data. International Journal of Innovative Research in Science, Engineering and Technology, vol. 7, pp. 8060-8071.

[30] Ugbor, D.O., and Okeke, F.N. (2010). Geophysical investigation in the lower Benue Trough of Nigeria, using gravity method. International Journal of the Physical Sciences Vol. 5, pp. 1757-1769.

[31] Ugwu, G.Z., Ezema, P.O. and Ezeh C.C. (2013). Interpretation of aeromagnetic data over Okigwe and Afikpo areas of lower Benue Trough, Nigeria. International Research Journal of Geology and Mining, Vol. 3, pp. 1-8.

[32] Ugwu, G.Z., and Ezema, P.O. (2012). Forward and inverse modelling of aeromagnetic anomalies over Abakaliki and Nkalagu areas of the Lower Benue Trough, Nigeria. International Research Journal of Geology and Mining, vol. 2, pp. 222-229.

[33] Verduzco, B., Fairhead, J., Green, C. and Mackenzie, C. (2004). New insights into magnetic derivatives for structural mapping. The Leading Edge, vol. 23, no. 2, pp. 116-119. https://doi.org/10.1190/1.1651454.

[34] Wright, J.B., Hastings, D.A., Jones, W.B. and Williams, H.R. (1985). Geology and mineral resources of West Africa. George Allen and Unwin, London. https://doi.org/10.1007/978-94-015-3932-6. 